Tale ved åbningen 15. marts 2005

af udstillingen

\section{Skyggebilleder. \\ H.C. Andersens rejse til Dresden og Sachsisk Schweiz 1831}

afmuseums-og kulturchef Ingrid Fischer Jonge

$\mathrm{D}$ eres Kongelige Højhed, mine damer og herrer, kære gæster.

Med udstillingen Skygge-

billeder. H.C. Andersens rejse til Dresden og Sachsisk Schweiz 1831viser Det Nationale Fotomuseum malerens, digterens og fotografens blik på Sachsisk Schweiz i det 19. århundrede og udstillingen går dermed på tværs af kunstarter og tid.

Titlen Skyggebilleder refererer til H.C. Andersens rejseberetning, som han udgav i 1831 efter en to måneders rejse til Dresden og Sachsisk Schweiz. Det var hans første udenlandsrejse overhovedet, og han var da en ung mand på 26 år, der et par år forinden havde opnået sit kunstneriske gennembrud som forfatter med rejseskildringen: Fodrejse fra Holmens Kanal til Østpynten af Amager.

Han havde også allerede en forlist drøm om et sprudlende teaterliv bag sig og man kan på sin vis sige, at Det Kongelige Biblioteks to udstillinger Digterens teaterdrømme og Skyggebilleder fortæller om de formative år, hvor H.C. Andersen afviklede sine barndomsdrømme og indledte vejen mod en ny identitet og selvopfattelse.

I maj 1831 steg han ombord på dampskibet i København og rejsemålet var Dresden. Og mødet med den romantiske digter Ludwig Tieck lå forude, som endemålet.

Denne tyske berømthed tog godt imod den talentfulde unge, høje mand, der kom med fine anbefalinger fra fælles venner hjemme i København.

A ndersen mødte også mange andre, ikke mindst den norske maler I.C. Dahl, der her fandt en digter, som oplevede verden lige så gerne med ord som $\mathrm{i}$ billeder.

For når man følger Andersen rundt i de sachsiske bjerge, kunne det have været en maler, der beskrev sine oplevelser. Hans evne til at fastholde synsindtryk med ord er legendarisk, men referencerne til det fotografiske billedes præcision ligger også snublende nær.

Hans første rejse gennem Europa er fuld af iagttagelser over småepisoder og landskabsvuer. Motiver, der skulle blive efterstræbt af kommende generationer af fotograferende turister. Blot små tyve år senere i 1853 blev hans fodspor i Sachsisk Schweiz fulgt af dresdener fotografen Herman Krone. Han var en af de allerførste landskabsfotografer i Europa og han fik stor betydning som læremester for yngre generationer.

Hvor Andersen var på opdagelse i de særegne og smukke bjergegne, drog den lokale Herman Krone ud i et velkendt område, hvor han på forhånd vidste, hvad han ville finde.

Jernbaner og broer havde gjort adgangen ulige nemmere end da Andersen var der, men det storslåede landskab lå fortsat uberørt hen.

Selvom Herman Krones fotografier afslører en visuelt begavet mand, så han ikke sig selv som kunstner, men som en videnskabsmand, der afprøvede den nye tek- 


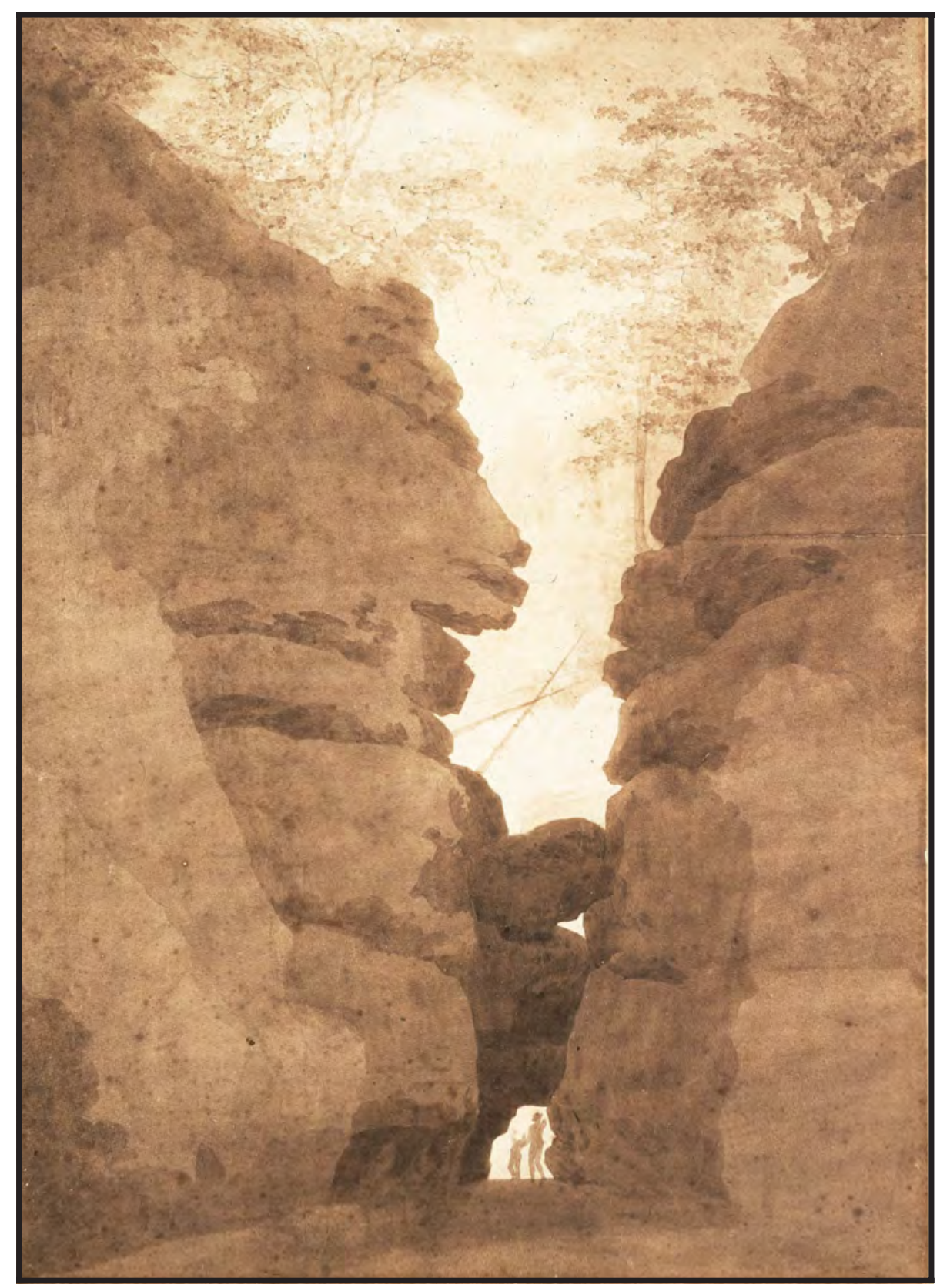

Caspar David Friedrich: Felsentor am Uttewalder Grund, ca. 1801. Sepia, 70,5 ×50,3 cm. 
nik, våd-collodium i naturen. Samtidig producerede han salgbare billeder til turister og havde ligesom borgerskabet et godt øje for "romantiske vuer".

Herman Krone var en moderne og driftig mand, der var dybt fascineret af den fotografiske teknik, som i hans hænder konstant var under udvikling. Det lykkedes ham at videnskabeliggøre fotografiet i et sådan omfang, at Technische Hochschule i Dresden i 1870 oprettede et professorat i fotografi til ham.

I 1908 blev det udvidet til et helt institut for fotografi med samme status som naboinstituttet i fysik.

Det var ganske andre følelser, den tyske romantiske kunstner Caspar David Friedrich oplevede, når han, små tyve år før Andersen, vandrede rundt i Sachsisk Schweiz.

Storheden og det sublime omsatte han i maleriske udsagn, hvor elementer fra Sachsisk Schweiz blev håndplukket og sammensat med andre landskabsformationer. Resultatet blev betagende, men også frygtindgydende billeder, hvor den ensomme vandrer konfronteres med naturens uendelige storhed og uovervindelige kræfter.

Disse mesterværker kendte I.C. Dahl på nærmeste hold, idet han boede i Friedrichs hus lige ned til Elben. Om Andersen nogensinde mødte Friedrich, da han besøgte Dahl i Dresden, ved vi ikke. Det nævnes ingen steder, og Friedrich var da også en travl mand, kunne være så mange andre steder i verden under de 14 dages ophold, H.C. Andersen havde i Dresden.

Udstillingen Skyggebilleder omhandler således en tidsepoke, der spænder fra romantikken til moderniteten, og Andersen repræsenterer her den typiske overgangsperiode, hvor det kendte erstattes med konturerne af det nye. Hvor romantikkens naturfilosofi erstattes af en rationel og konkret realisme.

$\mathrm{M}$ ed udgangspunkt i H.C. Andersens rejseskildringer, der er baseret på hans dagbogsnotater, folder udstillingen sig ud som en vifte, der både griber ud mod tiden før H.C. Andersen og tiden efter hans første besøg i Dresden. På den måde er det en meget atypisk udstilling for Det Nationale Fotomuseum, fordi kulturhistorie, billedkunst og litteratur her for første gang er føjet sammen til et hele.

For at løse en sådan opgave visuelt, har vi valgt at benytte en række af de udtryksformer, som er karakteristisk for samtidskunsten. Vi har omsat malerier af Caspar David Friedrich, I.C. Dahl, Gustave Öhme og andre til projektioner i kolossalformat og til tapet, der repeterer motivet. Den amerikanske popkunstner Andy Warhol viste allerede i 1960'erne, hvordan tapet kunne blive til andet end blot mønstre på væggen, og siden har en række billedkunstnere arbejdet videre med det koncept.

Med samtidskunstens visuelle greb har vi ganske enkelt forsøgt at formidle malerens, digterens og fotografens blik på Sachsisk Schweiz, men også Carl Maria von Webers romantiske opera, Der Freischütz, Jegerbruden, blander sig i koret, fordi også det er inspireret af Sachsisk Schweiz.

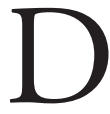
et er kunsthistoriker, mag.art. Ursula Fugmann, der fik ideen til udstillingen, og jeg vil gerne takke for et godt og inspirerende samarbejde.

Ich möchte auch Dr. Krase aus der Krone-Sammlung der Technische Universität in Dresden danken für grosse Hilfe und interessante Diskussionen.

Jeg vil også takke lektor ved Københavns Universitet Marie Louise Svane, 
de forskellige oversættere og andre flittige folk, som Jens Erdman Rasmussen og Christian Rud Andersen, der hver især har bidraget til at udstilling og katalog blev klar til tiden.

Vor hovedsponsor H.C. Andersen fonden 2005, Danmark \& Bikubenfonden skal heller ikke glemmes.

Til sidst vil jeg nævne, at det er billedkunstnerne Claus Teijl og Svend Danielsen, der har gentegnet henholdsvis
H.C. Andersens skitsetegninger og moderne grafiske højdekurver over Sachsisk Schweiz og det er skuespiller Søren Sætter-Lassen, der har lagt stemme til H.C. Andersens rejseberetning. Samarbejdet har været en fornøjelse. Vi håber selvfølgelig at publikum vil glæde sig over udstillingen og hvem ved - måske mødes vi til sommer i Sachsisk Schweiz.

Tak. 